of $\geqslant 15 \mathrm{IU} / \mathrm{ml}$ the fetus could be severely anaemic and therefore cordocentesis should be considered.

1 Nicolaides KH, Soothill PW, Clewell WH, Rodeck CH, Mibashan R, Campbell $S$. Fetal haemoglogin measurement in the assessment of red cell isoimmunisa. Fol hase

2 Rodeck CH, Nicolaides KH, Warsof SL, Fysh WJ, Gamsu HR, Kemp JR. The management of severe rhesus isoimmunisation by fetoscopic intravascular transfusions. Am f Obstet Gynecol 1984;150:769-74.
Nicolaides KH, Soothill PW, Rodeck CH, Clewell W. Rh disease: intravascular fetal blood transfusion by cordocentesis. Fetal Therapy 1986;1:185-92.

4 Marsh WL, Nichols M, Jenkins WJ. Automated detection of blood group antibodies. Fournal of Medical and Laboratory Technology 1968;25:335-42.

5 Nicolini U, Kochenour NK, Greco P, Letsky EA, Johnson RD, Contreras M, et al. Consequences of fetomaternal haemorrhage after intrauterine transfusion. $B M \mathcal{F} 1988 ; 297: 1379-81$.

(Accepted 13 fanuary 1992)

\section{Inhaled atrial natriuretic peptide and asthmatic airways}

\author{
Geoffrey Hulks, Neil C Thomson
}

Department of Respiratory

Medicine, Western

Infirmary, Glasgow

G11 6NT

Geoffrey Hulks, Wellcome

Research Fellow

Neil C Thomson, consultant physician

Correspondence to:

Dr G Hulks, Department of Respiratory Medicine, City Hospital, Edinburgh EH10 5SB.

$B M \mathcal{7}$ 1992;304:1156 cyclic AMP.
Pathophysiological plasma concentrations of atrial natriuretic peptide have been shown to have a bronchodilator effect in constricted asthmatic airways, ${ }^{12}$ and lower doses may decrease bronchial hyperresponsiveness, ${ }^{3}$ a hallmark of asthma. This observation is of considerable interest as animal models suggest that the intracellular action of atrial natriuretic peptide in the airway is mediated by cyclic GMP, ${ }_{4}$ whereas $\beta$ agonists, which are the current first line bronchodilator treatment for asthma, act through

Drugs for treating airway diseases are best given directly into the airway itself, and the purpose of this study was to ascertain any bronchoprotective effect of inhaled atrial natriuretic peptide.

\section{Subjects, methods, and results}

We studied eight subjects (three women) with atopic asthma. Their mean forced expiratory volume in one second $\left(\mathrm{FEV}_{1}\right)$ was $94 \%$ (SD $8 \%$ ) of the predicted value. All subjects showed at least moderate bronchial hyperreactivity to inhaled histamine-that is, histamine at a concentration of $\leqslant 2 \mathrm{mg} / \mathrm{ml}$, produced $\geqslant 20 \%$ fall in $\mathrm{FEV}_{1}$.

On three separate days subjects received either nebulised atrial natriuretic peptide $(0.1 \mathrm{mg}$ or $1 \mathrm{mg})$ or placebo in a double blind, randomised manner. FEV was tested at 30,90 , and 180 seconds after inhalation and immediately thereafter a single two minute inhalation of histamine was given in a dose extrapolated from the screening visit to produce a $25 \%$ fall in FEV $\mathrm{FEV}_{1}$ was measured again at 30,90 , and 180 seconds and repeated at $5,10,15$, and 20 minutes.

Forced expiratory volumes at baseline and after atrial natriuretic peptide were compared by analysis of variance.

There was no significant variation in baseline $\mathrm{FEV}_{1}$ between study days nor was there any significant change in $\mathrm{FEV}_{1}$ after atrial natriuretic peptide alone. All subjects showed a pronounced inhibition of histamine induced bronchospasm with $1 \mathrm{mg}$ atrial natriuretic peptide (figure). The maximum fall in $\mathrm{FEV}_{1}$ was 26.8 (SE 0.7 ) $\%$ with placebo, $22.6(3.3) \%$ with $0 \cdot 1 \mathrm{mg}$ atrial natriuretic peptide, and $9 \cdot 2(2 \cdot 2) \%$ with $1 \mathrm{mg}(\mathrm{p}<0.001$, placebo $v 1 \mathrm{mg}$ atrial natriuretic peptide). No side effects were reported or observed.

\section{Comment}

This is the first report that atrial natriuretic peptide effectively protects the hyperreactive airway when given by inhalation. The observation is of particular interest as atrial natriuretic peptide is believed to work by a linkage of guanyl cyclase and the generation of cyclic $\mathrm{GMP}^{4}$ and thus represents a different intracellular mechanism to $\beta$ agonists, for which the

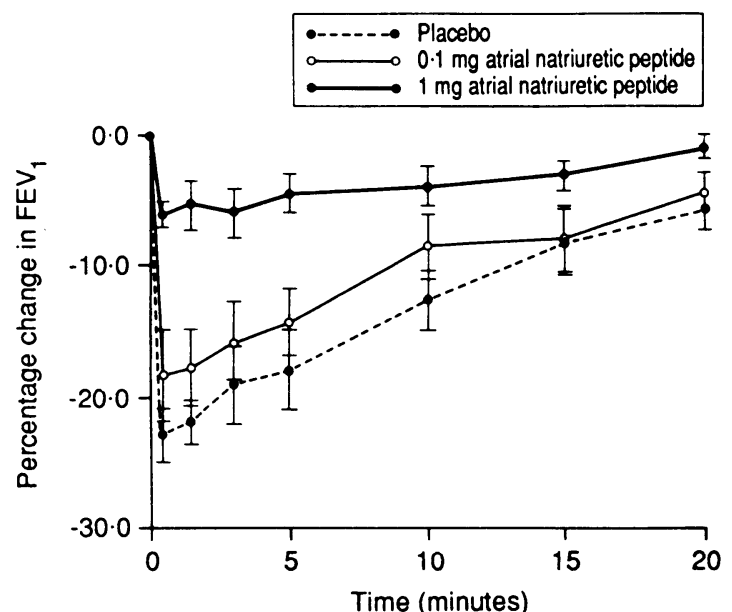

Mean (SE) change in forced expiratory volume in one second in response to inhaled histamine after pretreatment with inhaled atrial natriuretic peptide in eight asthmatic subjects

generation of cyclic AMP is linked to adenyl cyclase.

We assume that atrial natriuretic peptide achieves its effect by acting directly on smooth muscle in the airway. In support of this, animal models have shown that atrial natriuretic peptide in tracheal preparations has a direct, dose dependent, relaxant effect. ${ }^{45}$ Atrial natriuretic peptide has been localised by autoradiography to smooth muscle in rat bronchi and bronchioles, but a receptor population in the human airway has not been directly sought. It should be emphasised that other possibilities remain to account for the observed effect. Atrial natriuretic peptide has been shown to exert some of its renal effects by altering mucosal ion transport, and similar effects in airway smooth muscle might affect airway reactivity. Atrial natriuretic peptide can modulate vagal activity and ganglionic neurotransmission and, although this evidence pertains to vascular models, similar actions in the airway could be relevant.

We have shown that a substance believed to act by a different intracellular mechanism to current first line bronchodilator treatment for asthma has a significant bronchoprotective effect when given by inhalation. We therefore suggest that natural or synthetic compounds that work by a similar mechanism warrant further investigation as potential therapeutic agents to be given by this route.

GH was supported by a Wellcome medical graduate fellowship. The cost of atrial natriuretic peptide was met by a grant from the Chest, Heart, and Stroke Association (Scotland)

1 Hulks G, Jardine A, Connell JMC, Thomson NC. Bronchodilator effect of atrial natriuretic peptide in asthma. BMF 1989;299:1081-2.

Chanez P, Mann C, Bousquet J, Chabrier PE, Godard P, Braquet P, et al. Atrial natriuretic factor (ANF) is a potent bronchodilator in asthma. $f$ Allergy $C$ lin Immunol 1990:86:321:4.

3 Hulks G, Jardine A, Connell JMC, Thomson NC. Influence of elevated plasma levels of atrial natriuretic factor on bronchial reactivity in asthma. Am Rev Respir Dis 1991:143:778-82.

4 Ishii K, Murad F. ANP relaxes bovine tracheal smooth muscle and increases GMP. Am I Physiol 1989;256(Cell Physiol 25):C495-500.

5 O'Donnell M, Garippa R, Welton AF. Relaxant activity of atriopeptins in isolated guinea-pig airway and vascular smooth muscle. Peptides
1985;6:597-601.

(Accepted 20 January 1992 